\title{
Reflexivity of Anticipations in Economics and Political Economy
}

\author{
Patomäki, Heikki Olavi
}

Springer

2020

Patomäki , H O 2020 , Reflexivity of Anticipations in Economics and Political Economy . in R

Poli (ed.) , Handbook of Anticipation . Springer , Cham , pp. 1-26 . https://doi.org/10.1007/978-3-319-31737-3_16-1

http://hdl.handle.net/10138/318768

https://doi.org/10.1007/978-3-319-31737-3_16-1

Downloaded from Helda, University of Helsinki institutional repository.

This is an electronic reprint of the original article.

This reprint may differ from the original in pagination and typographic detail.

Please cite the original version. 


\section{Reflexivity of Anticipations in Economics and Political Economy*}

Forthcoming in R.Poli (ed.) Handbook of Anticipation. Theoretical and Applied Aspects of the Use of Future in Decision Making, Springer: Berlin.

[Next-to-final version with footnotes]

Heikki Patomäki

Professor of World Politics and Global Political Economy

Faculty of Social Sciences

P.O. Box 54 (Street address: Unioninkatu 37)

00014 University of Helsinki

Finland

tel. +358 - (0)50 - 4484400 (work mobile)

$+358-(0) 40-5184854$ (mobile)

fax. $+358-(0) 9-19124832$

E-mail: heikki.patomaki@helsinki.fi

* I am most grateful to Roberto Poli for patience, Niina Kari for research assistance and Jamie Morgan for comments.

All possible remaining errors in this article are, of course, my sole responsibility. 


\title{
Reflexivity of Anticipations in Economics and Political Economy
}

\author{
Heikki Patomäki \\ heikki.patomaki@helsinki.fi
}

\section{$\underline{\text { Introduction }}$}

Realist forms of economic theory acknowledge that any movement (such as prices or quantities going up or down) requires a temporal sequence of events, which makes it possible to specify causation in real historical time. The net outcome of many processes and mechanisms, however, can often be known only after the event (Robinson 1980). This seems to establish an asymmetry between explanation and prediction. We may be able to explain the past, but not predict the future.

Some risks may be calculable, but the future as a whole seems characterized by uncertainty. J.M. Keynes theorized uncertainty in his early work on probability (2008/1920) and then relied on this concept in his General Theory (1961/1936). Even when some economic regularities or functions (such as propensity to consume) appear stable in a given historical context, they may change in the future. This is a manifestation of what is called the problem of induction in the empiricist philosophy of science. Keynes discussed this problematic also in terms of probabilities. If probabilities are not stable and fundamental uncertainty prevails (as Keynes $1961 / 1936$ is usually read), it is difficult to say much about the future and certainly impossible to assign well-defined probabilities to possible futures (for a discussion on different concepts of uncertainty in economics, see Dequech 2011). At the same time, Keynes assumed that the formation of expectations is governed by loose empirical regularities related to the mass psychology of markets and investment moods. Waves of optimism and pessimism are part of business cycles in capitalist market economy, which indicates that expectations can have a self-fulfilling character.

Although Keynes acknowledged that anticipations can have an effect on the anticipated events and processes, he did not employ the terminology of reflexivity or self-altering prediction. The term "self-fulfilling prophecy" was coined by sociologist Robert K. Merton. Its logical counterpart is a self-denying prophecy, a prediction that alters the future against the original prediction. As an example of self-fulfilling prophecy, Merton (1948) discussed for example the case of a run on the Last National Bank in 1932. Merton's generic point was that public definitions of a situation involving anticipations of the future (prophecies, predictions) tend to become an integral part of the situation and thus affect subsequent developments. He also asserted that the situation-definition may be false but by evoking new behaviour, it will subsequently become true (Merton 1948, 195). In other words, behaviour based 
on false beliefs can generate a social situation that would seem to accord with those false beliefs.

Whereas economists have usually been keen to improve the accuracy of their professional predictions about GDP growth, unemployment, inflation and so on, many social scientists have been more interested in breaking the circle in which false lay actor anticipations sustain unnecessary, unneeded and unwanted social practices or structures. A social scientist may nonetheless be trying to predict the outcome of elections; and an economist may be interested in mitigating business cycles and related waves of optimism and pessimism. Either way, self-altering anticipations can generate complex combinations of self-fulfilling and self-denying tendencies occurring in open systems and in tandem with other mechanisms.

The 1970s was a break point for the Bretton Woods and related established economic policies. A series of political decisions and choices contributed to a rupture of existing institutional structures and their constellation in the world economy. At this time reflexivity moved to the forefront of economic theorisation. Economist Charles Goodhart explored the effects of the "competition and credit control" reforms that had been introduced in the UK in September 1971, removing direct controls on bank lending (the 1975 paper was republished e.g. in Courakis 1981). These reforms broke down the previously stable "money demand function". The money demand function was taken as an empirical regularity and useful control mechanism for monetary policy. Goodhart mentioned in passing a "Goodhart's Law", according to which "any observed statistical regularity will tend to collapse once pressure is placed upon it for control purposes" (Goodhart 1981, 116). The collapse can be due to individuals trying to anticipate the effect of a policy and then taking actions which alter its outcome.

Robert Lucas highlighted a similar but more general problem in econometrics. In his 1976 paper, Robert Lucas claimed that any change in policy will alter the structure of econometric models. A key belief in the 1960s and 1970s was that there is a simple trade-off between inflation and unemployment (the so-called "Phillips curve"). But reflexivity matters. From the "Lucas-critique" point of view, the problem with the Phillips curve is that permanently raising inflation in the hope that this would lower unemployment would over time cause firms' inflation forecasts to rise, altering negatively their employment decisions and causing inflation to accelerate.

David F. Hendry has tried to respond to the "Lucas-critique" from a realist angle by arguing that economies constitute dynamic complex processes. Dynamic complex processes "are often subject to major institutional, political, financial, and technological changes which manifest themselves as structural breaks in econometric models relative to the underlying data generation process" (Clements and Hendry 1999, 123). Hendry claims that these structural breaks can be included in econometric 
models. Some critics argue that economists such as Goodhart, Lucas and Hendry fail to take into account the more fundamental ontological point concerning the nature of being. All social systems are open and closed to a degree; and these systems include reflective actors that have the capacity to act otherwise (for discussions, see Lawson 1997, 71-4; Chick \& Dow 2005; Pratten 2005; Patomäki 2010).

It is not only that the net effect of many processes and mechanisms can often be known only afterwards; it is also that qualitative changes are possible through learning and structural and institutional changes. Social sciences themselves are regularly involved in these qualitative changes, especially through reflexive selfregulation of social systems. We can talk about reflexive self-regulation when claims about the way the social system functions are applied recursively in interventions, aiming at avoiding unwanted or achieving desired outcomes (cf. Giddens 1979, 7881). From reflexive self-regulation follows also the performativity thesis: economics conditions, shapes and constitutes the economy, rather than simply describing it (MacKenzie 2006; MacKenzie, Muniesa \& Siu 2007).

George Soros $(2008 ; 2013)$ has stressed the role of reflexive feedback loops (for a friendly critique, see Lawson 2015, ch 9). Participants' views and theories condition, shape and constitute but never fully determine events and processes; "while the course of events and processes influences but does not determine the participants' views and theories" (Soros, 2013, 313). As participants are not equal, some views and theories are more influential than others. Reflexivity is closely connected to fallibility. All views and theories are liable to be biased, incomplete, or both. Soros discusses "the efficient market hypothesis" that has not only legitimated financialization ${ }^{1}$, but has also constituted specific market practices and institutions. The increasingly prominent index-tracking funds provide an example of market practice that is inspired and based on the efficient market hypothesis (MacKenzie et.al. 2007, 4 et.passim.). Soros claims that financial markets are characterised by positive self-reinforcing reflexive loops driving participants' views and the real situation further apart. The widening of the discrepancy cannot continue forever. A self-reinforcing boom is then followed by a bust - as in the crash of 2008 .

I begin by discussing predictions and their accuracy in the light of Goodhart's law and Lucas-critique. In that context, I also examine Hendry's econometric response in a bit more detail and introduce the concept of contrastive demi-regularity. When the social reality is changing we need to know also what exactly is changing and why. I

\footnotetext{
${ }^{1}$ Financialization refers to the processes by which finance markets, finance institutions, and the elites involved in financing gain increasing hold over both private economic processes and public economic policymaking. Financialization involves deregulation and the growing scale and profitability of finance vis-à-vis the rest of the economy. (See e.g. Palley 2013). Van der Zwan (2014) distinguishes between three basic approaches to analyzing financialization: (1) the emergence of a new regime of accumulation; (2) the ascendency of the shareholder value orientation; and (3) the financialization of everyday life.
} 
approach these questions by analysing two significant real-world historical examples, the Euro crisis and global financial crises. Both examples involve reflexive predictions, reflexive feedback loops and performativity. What I find particularly striking is how the capitalist market economy - with all the historical shifts and changes in its institutions, regulations and political structures - has managed to retain at least some of its recurrent economic patterns.

Next, I examine the general methodological problem of the absence of decisive tests between theories. This has consequences: normative and ideological positions evolve easily and tend to fortify themselves rapidly; and actors can modify, perhaps inadvertently, their public anticipations in line with their interests or normative aims. In the final section, I argue that the main aim of social sciences is not to predict accurately but to bring about desirable outcomes, explaining how to move from strategic actions and reflexive ideologies to emancipation.

\section{$\underline{\text { Reflexivity, policy and changing social realities }}$}

Rational economic policy requires at least some predictive capacities. A choice of policy from a set $\left\{\mathrm{p}_{1}, \mathrm{p}_{2}, \mathrm{p}_{3} \ldots\right\}$ presupposes knowledge about the possible and likely consequences of $\mathrm{p}_{1}, \mathrm{p}_{2}$, and so on. In Keynes' theory, a key statistical regularity that can be used for predictive purposes concerns the multiplier effect of investments and public expenditure. In chapter 10 of General Theory, Keynes used the following estimates: marginal propensity to consume 0.8 ; the consumption rate for the unemployed is half of normal; and foreign trade accounts for $20 \%$ of the national income. On the basis of these rough facts, he estimated the multiplier in the 1930s UK should be in the order of 2-3. Every extra pound injected into the economy would yield an increase of 2-3 pounds in national product. Keynes stressed, however, that the multiplier depends on a number of historically changing connections within an interdependent economy. A large number of variables take part in determining the multiplier, directly or indirectly. Government policy and public investments have effects on many of them, for instance on interest rates and on general "confidence" and thereby on liquidity preference and marginal efficiency of capital.

The idea that policy can have an impact on economic events and processes and their relationships was thus not new in 1975 when Goodhart wrote his famous paper "Problems of Monetary Management: The UK Experience" (published also as Goodhart 1981). Until 1971, the pound had been pegged to the US dollar and this self-imposed constraint largely dictated monetary policy. The collapse of the Bretton Woods system in 1971 coincided with domestic reasons to reform the UK monetary system. In the few years before the "competition and credit control" reforms, the main money aggregates varied in a fairly consistent way with money incomes and interest rates. This seemed to indicate that the UK monetary authorities could use 
changes in the money stock to have a predictable effect on money incomes or on interest rates. They could also control the monetary aggregates through the price mechanism and stable demand-for-money function by lowering or raising interest rates. However, after the reform, banks changed their behaviour, reducing margins drastically to compete for market shares and increasing lending massively, especially to companies. This reveals that the demand-for-money function depends on the behaviour of banks and is dependent on the geo-historical context. Authorities' counter-measures were soon overtaken by other independent forces within the UK financial system, especially those related to the boom-and-bust cycle in the housing markets. This illustrates how, in open systems, the effects of historically evolving forms of agency, forces and tendencies can be delayed, overlapping, mutuallyreinforcing and/or contradictory.

It is not clear that the problem in 1971-5 in the UK stemmed from the pressure placed upon the demand-for-money function for control purposes. Deregulation led UK banks to change the rationale of their actions quite independently of the control purposes by the state. What matters is that Goodhart recognised that social realities change. Similarly, Lucas (1976) started his critique of empirical macroeconomic modelling by pointing out how econometricians rely on adaptive modelling, giving more weight on recent than distant experiences. Adaptive econometric modelling gives a better empirical fit, but it also indicates that the temporally distant data is less relevant and potentially misleading. The obvious explanation of this econometric practice is that because actors, practices, policies and institutions are changing over time, only recent experiences are really applicable. Lucas is interested in the role of state-policy. The crux of his argument is that any intervention such as a policy change affects the expectations and actions of the actors. What Lucas has been able to show is that the probabilistic relationships identified in econometric models are unstable (Lawson 1997, 69-85). Contra Lucas, however, the way and extent to which expectations and actions change are contingent and must be examined empirically. ${ }^{2}$ Moreover, actors' views can be contradictory and are subject to fallibility.

Any combination of self-fulfilling and self-denying tendencies occurring in open systems and in tandem with other social forces, tendencies and mechanisms is in principle possible. A "compensated" prediction tries to take into account also reactions to the prediction itself (cf. Grunberg \& Modigliani 1954; Simon 1954). Attempts to anticipate responses to predictions or regulations or changes in policies are subject to uncertainty, and anticipations may thus fail. The overall net result may

\footnotetext{
${ }^{2}$ Lucas proposed both a practical and theoretical solution to the ensuing problem of instability, which he assumed to be a problem that must be overcome. The practical solution was economic policy based on fixed and consistent rules rather than discretion. The theoretical idea was to rely on "rational expectations". Lucas and his followers have thus contended that responses to changes in policy are well understood and predictable. Moreover, the lay-actors are assumed to have perfect foresight. Lucas's practical solution has had a major impact on economic policy-making across the world and thus is a good example of the performativity of economic theory. His theoretical solution contradicts the epistemic principle of fallibility, however, and is thus utterly implausible.
} 
be either to increase or decrease predictive accuracy. Different cases can be distinguished depending on the dominant self-altering tendency and whether the prediction takes form of ordinal or scalar prediction, as depicted in Figure 1.

Figure 1: Effect of prediction form and dominant self-altering tendency on predictive accuracy

\begin{tabular}{lll}
\hline Prediction form & Dominant self-altering tendency \\
\hline & $\begin{array}{l}\text { Net self-fulfilling } \\
\text { tendency }\end{array}$ & $\begin{array}{l}\text { Net self-denying } \\
\text { tendency }\end{array}$ \\
\hline $\begin{array}{l}\text { Ordinal prediction } \\
\text { direction of change }\end{array}$ & \\
passing a benchmark & Increases accuracy & Decreases accuracy \\
\hline \hline
\end{tabular}

Scalar prediction Uncertain effect on Decreases accuracy

accuracy

Source: Henshel 1993, 98

For instance, a credible forecast of increased inflation is published by a central bank, ministry or research institute. This can bring about both self-denying (monetary and financial countermeasures by the government and central bank) and self-fulfilling responses (workers increase wage demands, corporations increase prices). If the net effect is self-fulfilling and the prediction is ordinal, these responses will increase the accuracy of the forecast. If the prediction is scalar and takes the form of precise number within a given time-interval, however, the effect on accuracy is uncertain, as the prediction may also cause an "overshoot". If the net tendency is self-denying, then accuracy is always decreased, independently of whether the prediction is ordinal or scalar. In this example, the purposefully self-denying policy responses are then subject to the instability diagnosed by Goodhart and Lucas, but in a manner that is not reducible to any simple predictable scheme or canon of economic theory. ${ }^{3}$ However, the significance of this instability is contingent and context-dependent.

\footnotetext{
${ }^{3}$ Lucas relies for instance on Milton Friedman's (1957) permanent income hypothesis, which he takes as an established part of the canon of economic theory. In practice, it is quite tricky to test Friedman's hypothesis because it is difficult, if not impossible, to distinguish between predictable and permanent income changes from other income changes.

Friedman himself used contradictory definitions: sometimes only the subjective assumptions of people matter; at other times the current wealth or past income matter, defining rational expectations about the future. By appropriately manipulating the definition and data, any desired result can be achieved. The real question is to what extent do people in
} 
Several economists have accepted instability and yet defend the use of statistical techniques (e.g. Sims, Goldfeld and Sachs 1982). The main claim is that although econometric projections are only conditional, they can be useful in policy analysis. Robert J. Gordon $(1976,57)$ argues further that "it may be possible in some cases to either deduce or estimate the shifts in parameters in response to policy changes". Hendry $(1983 ; 1985)$ has developed methods that can identify structural breaks, regime shifts and technological and financial innovations by means of econometric models and in future scenarios. This is important not least because these breaks and shifts tend to go hand in hand with episodes of dramatic predictive failure. Hendry's approach is explicit about not requiring closed systems (conditions similar to laboratory experiments, where the effects of one transfactual causal mechanism can be isolated and studied separately) and it allows for changes in parameters. The complex process generating data is local. Partly by identifying what is relatively constant in the process and partly by using insights from theory and practice, it is plausible to design a model that can be used as a tool in policy-making.

Hendry (1997) has also built methods of forecasting in a situation where there may be discrepancy between the model and the changing social world. There is no practical use of a model, however, when its key parameters are not stable, not even locally. Hendry (ibid. 1331) points out that the success of econometric model-based forecasts depends upon there being regularities that are informative about the future. In addition, we should be able to exclude non-regularities that swamp the regularities. A further problem of econometric modelling is that given the nature of available data and the absence of robust relations between variables, correlation- and regressionanalysis may rely on measuring something with precision that is not precise at all (Martins 2018, 231-2). These points bring us back to the ontological question.

Tony Lawson $(1997,204-13)$ has introduced the concept of contrastive demiregularity, indicating the existence of partial closures also in society. Contrastive demi-regularities concern contrasts between categories or spacetime areas and are expressed in terms of regularities within a given range of variation with certain probability. They are not strict regularities but probabilistic, limited to a particular spacetime area, and liable to change with the underlying structures and mechanisms. Lawson argues that it is not sufficient to find contrastive demi-regularities and, then, specify the conditions of their continuation. Rather, there should be a movement towards analysing the deeper social structures and causal mechanisms generating

\footnotetext{
practice calculate their consumption according to the expectations of tens of years? Of course, people's consumption can exhibit stability and planning to some extent. Expected short-term fluctuations can be offset by debt or savings. People adjust their consumption to others" consumption and often try to mimic the wealthier. Keynes, however, argued that in practice, many people consume roughly a standard part of their income, although standards also change over time, and this claim has support from both everyday experiences and empirical studies. See Keynes 1961/1936, 89-131; Wilcox 1989; and Chao 2000. For a more human and social hypothesis about relative incomes, see Duesenberry 1949; and for a strong-worded criticism of Friedman's biased practices of empirical research, see Herman 1995, 34-37.
} 
these manifest phenomena. Systems are nonetheless characterised by some continuity and stability at the empirical level as well.

Contra Lawson's theoretical and practical intentions, it may be reasonable to search for contrastive demi-regularities also as partial guidance to and illumination about possible and likely short- to mid-term futures. Contrastive demi-regularities are pervasive also in relatively open systems, and many aspects of world futures are very difficult to study systematically without a resort to some extrapolation. Although not the only task of future-oriented social science, the anticipation of possible and likely outcomes of actions, policies and regulatory and institutional changes is an important part of what rational social science should be doing. The real choice is between the use of (i) formal but only relatively and ambiguously adequate statistical methods and (ii) informal methods, including conceptual models that may involve some numerical values; theory-laden extrapolation; leading indicators; expert discussions and judgements, and so on. These options may also be seen as complementary.

\section{$\underline{\text { Reflexivity, regime shifts and structural changes in global finance }}$}

When the social reality is changing we also need to know what exactly is changing and why. To what extent, and when exactly, may self-altering predictions be sufficient for structural changes in the economy? In what ways are policy- and regime-shifts constituted by reflexive feedback loops and by performativity? How may these be related to technological and financial innovations? By answering these questions we are in a better position to anticipate the instability diagnosed by Goodhart and Lucas. Perhaps we could even anticipate the direction of likely responses, thus increasing our reflexive predictive capabilities. I approach these questions by analysing two significant real-world historical examples, the Euro crisis and global financial crises (especially 2008-9 and the next one).

\section{The Euro crisis: the role of institutionalised reflexivity}

The establishment of the Economic and Monetary Union in the Maastricht Treaty constituted a major regime shift in Europe. The EMU design, developed in the late 1980s and early 1990s, drew heavily on the ideas of monetarism, supply side economics and new classical macroeconomics, which came into vogue in the wake of changing circumstances (the partial collapse of the Bretton Woods system) and various intellectual developments (such as Lucas-critique). Established in the Maastricht Treaty, the European Central Bank sets interest rates, aiming for low inflation within the single market of the EU. No other common economic policy is deemed necessary. 
The expectation derived from abstract theory is that if economic policy is rule-based and price levels can be kept stable, economic growth will be strong and income levels in the whole of Europe will converge over the long term. This idea is based on new classical macroeconomic models developed in the 1970s and in vogue in the 1980s (on the 1970s neoclassical theories in which European Central Bank monetary policy is rooted, see e.g. Lucas 1972; Barro 1974; Sargent \& Wallace 1975). These models imply that market actors' perfect knowledge and rational expectations inevitably obviate (most of) the effects of Keynesian economic policy. Active economic policies can only serve to bring about higher inflation, an undesirable outcome. A further assumption was that well-functioning labour markets would even out regional differences, resulting in a balanced and affluent EU.

The short-lived process of apparent economic convergence ended in the global financial crisis of 2008-9. The global economic crisis triggered automatic stabilizers in the EU countries. Many of the countries also resorted to deliberate increases in national expenses to stimulate the economy. These expenses were paid off with new public debt, which was also used to shore up the rapidly depleting reserves of banks and investors. The euro crisis started when the rising levels of public debt triggered new credit assessments, negative market reactions and EMU's disciplinary mechanisms. (For the full story involving major design flaws and imbalances in the composition of efficient demand in the EU, see Patomäki 2013, ch 4.)

The key idea of the EMU is to discipline public finances through market mechanisms and to control the supply of money so as to keep inflation as low as possible. If public sector budgets are not in balance, the state or municipality must take on debt from the private sector, thereby making themselves vulnerable to interest rate increases. Even though Eurozone countries are still free to borrow on the domestic market, they have no control over the interest rates, which are determined in the financial markets. Transnational commercial banks set their own margins for the loans, based on their profit goals and on their assessment of the risk involved in granting the loan. Because the European Central Bank refused, in the beginning of the euro crisis, to intervene in market developments, for example by ensuring specific interest rates for certain Eurozone countries, market logic determined the price levels on the bond market.

Despite their convoluted nature, the difference stages of the finance game can be reduced to a fairly schematic chain, which can easily generate self-fulfilling predictions. During the euro crisis, the speculation chain went as follows (see Centre for Research on Multinational Corporations 2011; Patomäki, 2013, 75-6):

$\rightarrow$ Investment banks, for example Goldman Sachs or Deutsche Bank, and various hedge funds buy up credit default swaps - derivatives that function as guarantees against credit risk — in case Spain, Ireland, Greece, Portugal, or 
some other country becomes insolvent. These swaps can be bought even if the investors who buy them have no bonds issued by the countries in question.

$\rightarrow$ Increased demand for credit default swaps is interpreted as a sign that the economic situation in the country in question is deteriorating.

$\rightarrow$ Credit rating agencies, such as Moody's or Standard \& Poor's, react to the increased demand for bad credit swaps and reduce the creditworthiness rating of the country in question.

$\rightarrow$ The credit rating agencies' intervention raises the price of the credit default swaps, which makes it possible for speculators to make short-term profits, which increases the demand for swaps still further.

$\rightarrow$ Banks with bonds issued by a crisis-hit country become alarmed and begin to sell off the bonds. In some cases, they are legally obliged to sell bonds if their value drops below a certain level, since retaining them would increase risk of loss to the banks.

$\rightarrow$ If the crisis countries' bond prices drop significantly in value, it becomes profitable to "sell them short". Short-selling means that speculators first borrow the assets from some party and sells them at the going market price. Once the price drops, speculators buy the same assets back and then "return" them to the lender. Short selling strengthens the tendencies of assets to depreciate.

$\rightarrow$ The outcome of all the foregoing stages is that the crisis country finds itself in a situation in which it can renew its loans only by agreeing to exorbitant interest rates, as high as twenty or thirty percent or even much more (interest rates can climb up to hundreds of percent). This dramatically worsens its debt situation.

Overall, this is a system of circular causal relations. A relatively small change in one item initiates a sequence of events affecting others, eventually returning to affect the item that began the sequence in a self-reinforcing manner. The causal forces in this loop do not operate blindly but rather involve self-regulation through feedback via the operation of selective information filtering and interpretations (based on particular technical concepts and theories of finance and economy). The feedback takes the form of predictions that affect credit ratings and market valuations and tend to be self-fulfilling. The system as a whole is based on reflexive self-regulation to the extent that it is purposefully employed in order to discipline public finances through market mechanisms. The system also generates unintended consequences such as financial crises that would not occur in the absence of this causal loop.

Within the prevailing framework, however, the deep crisis of several Eurozone countries was usually interpreted as a moral failure of the governments and as weakness of EMU discipline. The main exception has been European Central Bank's 
"unconventional monetary policy", starting with the Outright Monetary Transactions (OMT) programme that was announced by the Bank's Governing Council in August 2012. The ECB promised to use central bank money to buy bonds from the secondary market as needed. Since the central bank can easily create money, the sale of bonds is now guaranteed. This has calmed the money market and helped to keep interest rates relatively low, although the crisis in its various phases continued until 2015, with a weak and fragile recovery starting in 2016.

The course of events in the process known as the Euro crisis have influenced actual policy (ECB) without, however, altering the main participants' (the troika, the Eurogroup, mainstream economists) views about the underlying economic and political theories. ${ }^{4}$ In line with the prevailing theoretical framework, a number of new institutional arrangements have been introduced or put in place: the stability mechanism, the "six-pack", the "two-pack", the European Fiscal Compact and the euro plus. Both "preventive" and "correcting" mechanisms of these arrangements rely largely on economic forecasts, which without planning are difficult to carry out and make corrections. For instance, the 2012 European Fiscal Compact involves concepts such as "structural deficit", "cyclically adjusted debt-to-GDP ratio" and "MediumTerm Budgetary Objective" (MTO), which all make references to the future:

In the event of significant observed deviations from the medium-term objective or the adjustment path towards it, a correction mechanism shall be triggered automatically (Council of the European Union 2012, 6).

The Compact stipulates that the government budget should either be balanced or in surplus. It introduces the concept of the structural balance, which refers to the budgetary position of the state when adjusted for cyclical effects, based on estimates of potential GDP. The structural balance ought to converge with the country-specific medium-term objective according to a timetable set by the Commission. Signatories must also set up automatic correction mechanisms at the national level, preferably in the constitution to ensure that any deviations are quickly corrected. States breaching deficit limits need to put forward a plan for structural reforms, assessed by the Commission and the Council. If a member state is in an excessive deficit procedure, the matter can be brought to the European Court of Justice, who can impose sanctions up to $0.1 \%$ of the GDP of the deviant state (Council of the European Union 2012, 8).

Each member state must specify which institute is responsible for the economic forecasts used in their calculations. The authority of the last resort in this regard lies,

\footnotetext{
${ }^{4}$ It is noteworthy that the concept of uncertainty can itself become an obstacle to learning, as seems to be the case for instance with the Bank of England after the global financial crisis 2008-9. As Nasir and Morgan argue (2018, 21), "the use of uncertainty as a justification can become a barrier, which short-circuits learning because theory and method do not respond to failure at a fundamental level. This seems a very basic contradiction for central banking, the nature of an open system periodically undermines forecasting, but forecasting is insulated from assimilating this insight because of the use to which a concept of uncertainty as unavoidable error can be put in an open [and reflexive] system."
} 
however, with the EU Commission itself. Forecasts affect economic policy, in turn affecting economic developments. Forecasts are thus not independent of what possibilities will be actualised. Predictions or forecasts can be "optimistic" or "pessimistic" depending on what is assumed to be normal as well as on what normative aims are implicit in the background theories (e.g. downsizing the public sector). ${ }^{5}$ Predictions of low economic growth in the future are thus likely to become self-fulfilling. For ordinal predictions, this will increase their accuracy, but for cardinal predictions, the effect is uncertain because of the possibility of overshoot.

A key issue in this system is that attempts to reduce public debt can turn out to be self-defeating and recessionary. Through cuts in public expenditure, disposable income is reduced thus potentially inducing or worsening an economic recession through the multiplier effect. This, in turn, leads to decreased tax receipts and increased expenditure due to the workings automatic stabilisers, such as unemployment benefits. When combined with a fall in GDP, this increase in expenditure results in an increase of debt-to-GDP ratio, potentially leading to a vicious cycle. Crucially however, whether this dynamic is played out depends on the policies of other actors in the system and the prevailing phase of the business cycle, which is not independent of these policies though not reducible to them. Overall, this system is an example of institutionalised reflexive loop that is geared toward an implicit political aim involving a high likelihood of net self-fulfilling tendency toward harmful socio-economic outcomes (to be analysed in more detail below).

\section{Global financial crises: the role of recurring patterns}

The Euro crisis was instigated by the global financial crisis of 2008-9, a dramatic example of a crash following worldwide bubble. The boom-and-bust cycle involves reflexive feedback loops. According to Soros (2013, 323; see also Soros 2008), a boom-bust process is set in motion when a trend and a misconception about it positively reinforce each other. Behaviour based on false beliefs - in the 2000s actively supported by the majority of economists - contributes to a trend that would seem to accord with those false beliefs. The course of events and processes in financial markets reinforces participants' views ("bull market") and theories ("efficient market hypothesis"). Reflexivity works also through changes in the economy itself, not only via beliefs. For instance, the value of homeowners' or investors' collateral is not independent of the availability of credit. When credit

\footnotetext{
${ }^{5}$ For instance, projections by the Commission in the spring of 2018, during a period of economic growth, forecasted that Romania will have the most significant deviation in its structural budget position at $-3,8 \%$ of potential GDP with Hungary at $-3,6 \%$ as a close second. Both were placed under Significant Deviation Procedures. Surplus countries included Greece $(2,5 \%)$, Germany (1.2\%), Sweden $(0.7 \%)$ and Denmark $(0.3 \%)$. Italy and France were both predicted to have structural deficits at $-1.7 \%$ and $-2.1 \%$ respectively. For the euro area as a whole, the Commission forecasted a structural budget position at $-0.8 \%$ of potential GDP in 2018 and $-1.1 \%$ in 2019. (European Commission 2018, 180)
} 
becomes cheaper and more easily available, activity picks up and values rise. The amount of credit is at its maximum at the height of the boom.

The boom is sustained not only through evidence from the markets but also by "analytical monocultures", i.e. shared models, metaphors and narratives, creating theory-data-theory feedback loops. Uncertainty reinforces this tendency to resort to prevailing beliefs and stories and analyse data accordingly. (Bronk 2013; also Patomäki 2001, 21-25). Thus constituted expectations can be self-reinforcing for years, but the collective consequences of leverage building, mutual indebtment and rapidly inflating asset prices mean that the process becomes unsustainable and will turn downwards sooner or later (Minsky 2008). Certainty that an inflationary process has constituted a bubble can only be established ex post, i.e. after its bust, although ex ante indicators and historical analogies often are sufficiently reliable for many practical purposes. There are two mechanisms that finally will bring the boom to an end. The first has to do with the growing discrepancy between asset values and reality understood in terms of how much revenues are really generated (Soros 2013; Shaikh 2013). The second is that the rising involvement in debt makes the system gradually more vulnerable to relatively small disturbances, and thus increasingly chaotic. The monetary system is stable only as long as streams of revenue and profit enable firms to meet their financial liabilities (Minsky 1982, 22; see also Patomäki 2010)

When the confidence on the prospects of $\mathrm{X}$ is gone, the individually rational choice of "sell as quickly as you can" can amount to a collectively catastrophic outcome of a collapse of asset values although overall most investors would be better off by not selling for the time being. Markets involves contradictory tendencies: complicated bets can be made on a bust or crash and some may also benefit from "bear markets". A catastrophe occurs when most actors believe that the worst outcome would be to stay in now while most others opt out. By not selling as quickly as they can, they would be easily left with very little (and for some actors there are specific more formal mechanisms, such as covenant breaches and collateral margin calls creating "death spirals"). Many assets remain valuable only as long as other cross-invested assets remain valuable. If an actor becomes insolvent, it affects many others' stream of revenue as well. Hence, the occasional bursts of panics and busts, with farreaching causal consequences to production, employment and welfare.

In the 1970s, a regime shift occurred that led to a structural change increasing volatility and enabling positive reflexive loops generating boom-and-bust cycles. Since then, the process of financialization has been an on-going process with sporadic changes in the way the financial markets operate (after major crises, there have also been periods of counter-regulation). Innovations are a part of these shifts and changes. Capitalist market economy generates innovations also in finance, not only in production and exchange (see Minsky 1982, 2008). New financial instruments and other financial innovations presuppose de- and re-regulation, usually justified in 
terms of "efficient markets". Financial innovations are in some ways analogical to the effects of Schumpeterian innovations, aiming at ensuring something analogical to monopoly profits as long as possible (cf. Schumpeter 1939, 87-125).

In financial markets innovations concern first and foremost leverage and the management of risk. At least partial secrecy or non-transparency is essential for hiding uncertainty, for masquerading uncertainty as calculable risks, and for profitably transferring and re-pooling risks. Financial innovations are often also about increasing leverage or decreasing the time of the investments or capital requirements, both of which mean new risks and uncertainty. Sometimes innovations are needed to evade regulations. Arguably, nearly all financial innovations prior to the global crash of 2008 were at variance with the common good (e.g. Stiglitz 2010). The overall effect of the bulk of financial innovations was to strengthen the unsustainable boom, also by making credit easier and finance more fragile, until the crash of 2008.

From a theoretical point of view, it is striking how the capitalist market economy with all the historical shifts and changes in its institutions, regulations and political structures - has managed to retain at least some of its recurrent economic patterns (Shaikh 2016; see Patomäki 2017)? I have puzzled over this question for nearly two decades, since the Asian crisis of 1997-98, and since I first learnt about the tendency in capitalist market economy towards financialization, which then gives rise to a recurring tendency toward a pattern of booms and busts (see Kindleberger 1978; Minsky 1982; Soros 1998; cf. Patomäki 2001, chapter 2). What is especially remarkable is that reflexivity and reflexive loops can be part of patterns that tend to be recurring over the timespan of centuries (since the 1720 South Sea Company crash), making at least some generic things anticipatable at least at some level of abstraction. Such recurring patterns also point to lack of long-term rational learning, Bayesian or otherwise, further undermining the validity of new classical models.

In contrast to 2006-7, in 2016-18 many well-known analysts and international organizations from Deutsche Bank to the IMF have been warning about a future crisis that might occur in 2018, but is likely to come about by 2020 (Reid et al 2017; IMF 2016; IMF 2017; IMF 2018). Anticipations are reflexive and can have effects on the future. Moreover, some economists believe that central banks have learnt new lessons from their unconventional policies and are now ready and willing to use their - in principle unlimited - resources to prevent a financial collapse from happening. Are we thus safer in the late 2010 s and early 2020 s than before?

Past lessons and reflexivity have effects through transforming actions and institutions. We are not, however, seeing attempts to counter the process of financialization for instance through re-regulation or taxation of global finance, reduction of inequalities, or establishing new programmes of stimulating productive investments. There are some global initiatives via the Basel Rules and via the 
international Financial Stability Board but these are highly limited, involving more retained capital and centralised systems for derivatives that are based on the premise that rational actors with more information (about shadow banking etc.) will render the system more robust, enabling more "financial deepening". This follows variations on "efficient markets" frameworks. Meanwhile, the Trump administration is giving significant tax benefits to the super-rich and deregulating finance. Even in the EU, the project of establishing a financial transaction tax seems to have come to an end, and the European financial union is lacking sufficient resources. The rising debt levels in China are an increasing global concern, although interpretations about its significance differ. Meanwhile, the global bubble in stock and housing markets has been growing, although the latter boom may have already seen its peak in summer $2018 .{ }^{6}$

A lot hinges upon central banks, but they are in a contradictory position, and not only because their public predictions tend to be self-fulfilling. The very attempt to tighten policy in order to return to the "normal", to respond to inflation, or to slow down the growth of bubbles may set in motion a downward spiral for instance by triggering sovereign debt crises or by increasing the burden of debt among investors and homeowners. And to reiterate, central banks may simultaneously fear that any anticipation of tough times may become self-fulfilling. In the absence of adequate common policies, regulations and institutions on a global scale, central banks may actually be less powerful than often thought. Hence, Minsky's "it" (the collapse of the financial and economic system) seems again rather likely. If my analysis is on the mark, we are likely to see a major crash - perhaps even bigger than in 2008, although this is uncertain - followed by a global recession or depression, by 2020 or so. ${ }^{7}$ A precise prediction of the timing of the next crisis would make it possible to exploit the crash. If acted upon widely, such a prediction could also become self-fulfilling.

\footnotetext{
${ }^{6}$ See for instance "There's trouble ahead in the global housing market", Business Insider 17 July 2018, available at https://www.businessinsider.com/housing-market-prices-about-to-plummet-worldwide-2018-7?r=US\&IR=T\&IR=T; and The End of the Global Housing Boom, Bloomberg News, 1 August 2018, available at https://www.bloomberg.com/news/articles/2018-07-31/are-house-prices-falling-from-sydney-to-new-york.

${ }^{7}$ In August 2018, five economists, three of whom (Peter Schiff, Steve Keen and Dean Baker) forecasted ex ante the 2008 financial crisis, tried to anticipate the shape of things to come. Four of them expect a downturn in the next two years or so, in most cases either caused by erroneous central bank policy or a series of local busts; only one of them (Peter Schiff) expects a major global crash. For instance, Keen argues that there is no major financial bubble and "China is the biggest economy facing a credit crunch, but its huge level of government spending is already softening the blow". See the salon forum "The end really is near: a play-by-play of the coming economic collapse" available at https://www.salon.com/2018/08/12/the-end-is-near-a-play-by-play-of-the-coming-economic-collapse/. It seems to me that these anticipations underestimate for instance the bubble in stock markets. In summer 2007, Dow Jones index almost reached 14,000 points just before the crash; in 2018 it has been above 28,000 points. Meanwhile, the US economy has grown only $15 \%$ and GDP/capita $6 \%$. On the other hand, FTSE 100 index for example is a mere $16 \%$ above the summer 2007 peak levels, with corresponding GDP/capita growth of less than 4\%. It is also noteworthy that in the second quarter of 2018 global debt reached a new peak, climbing to 260 trillion dollars $(\$ 260,000$ billion); at the same time, the global debt to GDP ratio crossed the 320\% threshold for the first time (Minenna 2018).
} 
$\underline{\text { Strategically and ideologically motivated predictions in open systems }}$

Often predictive accuracy is not a reasonable aim of social sciences. This is especially true when reflexivity is involved. Self-altering predictions can move the world into a direction that may or may not be desirable. A net self-fulfilling tendency usually - though not always - improves accuracy (see Figure 1), but if the predicted outcome is worse than what would have occurred in the absence of the prediction, improved accuracy is harmful. A net effect of self-denial decreases accuracy, but this is normally good if the self-alteration helps for example to reduce unemployment or make growth more sustainable, not to speak of avoiding sudden crises or wars. This suggests two somewhat contradictory criteria for an adequate prediction: relevance and accuracy, on the one hand, and success in informing practical actions and shaping the world, on the other. The contradiction can be mitigated by defining accuracy counterfactually: what would have happened in the absence of prediction?

One implication is that self-altering predictions can only be tested and thus falsified by means of counterfactual reasoning: what would have happened, had X been otherwise? Here X denotes reflexive phenomena such as predictions, but a systems' openness more generally should also be taken into account. Even when the predictive analysis of relevant forces and tendencies is valid, in open systems qualitative changes or extrinsic interferences may occur in a manner that is not anticipatable, including in terms of chances and coincidences. While all causal analysis involves counterfactual reasoning ("had X been otherwise, would Y have occurred?"), reflexivity and ontological openness of reality introduce a further non-testable element into social sciences, making ex post falsification of predictions difficult. This reflects and further complicates the general methodological problem of studying open systems. The general methodological problem is that in the absence of closure, decisive tests between theories are hard to come by. Hence, normative and ideological positions evolve easily and tend to fortify themselves rapidly. ${ }^{8}$

As actors know that anticipations tend to become an integral part of the situation and thus affect subsequent developments, including policies, they can modify, perhaps inadvertently, their public anticipations in line with their interests or normative aims. Consider the case of self-interested strategic predictions. Eerik Lagerspetz (1988, 309-12) discusses the tendency of energy producers to overestimate future energy needs. Lagerspetz depicts a (hypothetical but evidence-based) mechanism that generates self-fulfilling prophecies and unnecessarily large energy-production

\footnotetext{
${ }^{8}$ From this point of view, Roy Bhaskar $(1998,23,50,144)$ analyses the consequences of the continuing hegemony of positivism. Because of the absence of decisive test situations, coupled with continuing one-sided allegiance to a mere predictive rather than explanatory and other criteria, the methodology on which one's research relies gets mystified. The dominant or otherwise privileged theory is thereby protected, alternatives are stunted, and there is an encouragement of (a belief in) the unresolvability of theoretical conflicts — which, in practice, means their resolution in favour of the status quo. I would not go as far as Bhaskar, however, in making the criteria for the rational appraisal and development of theories in the social sciences exclusively explanatory. Our predictive powers matter, but in a complicated manner.
} 
capacities. The producers predict an increase in consumption and then start to increase production as a response to this anticipated need. Consumers, including industry, expect cheap energy also in the future because of the growing supply and thus increase their consumption. New consumption patterns are adopted. The prediction that consumers are going to move into certain direction thus induces the predicted move, although it is undesirable from a sustainability viewpoint.

Wishful thinking can shape anticipations also for non-self-interested reasons. It is not only that expectations and anticipations can turn out to be self-fulfilling or selfdenying; this may also be part of their very purpose. The performativity of economic theory illustrates this problematic. The efficient market hypothesis - not only in the context of financial markets (Fama 1970) but also more generally - promises welfare gains, if not in the short run then at least in the unspecified, non-historical "long run", from balanced budgets, low inflation, trade-liberalisation, deregulation, privatisation, outsourcing and several other policies. With hindsight and a firm commitment to the theory, it is always possible to find a variety of ad hoc explanations for the unintended consequences that these policies tend to have in concrete historical contexts. This can result in a closed circle, as summarised in the scheme of Figure 2.

Figure 2: The closed circle of operation of the efficient market hypothesis

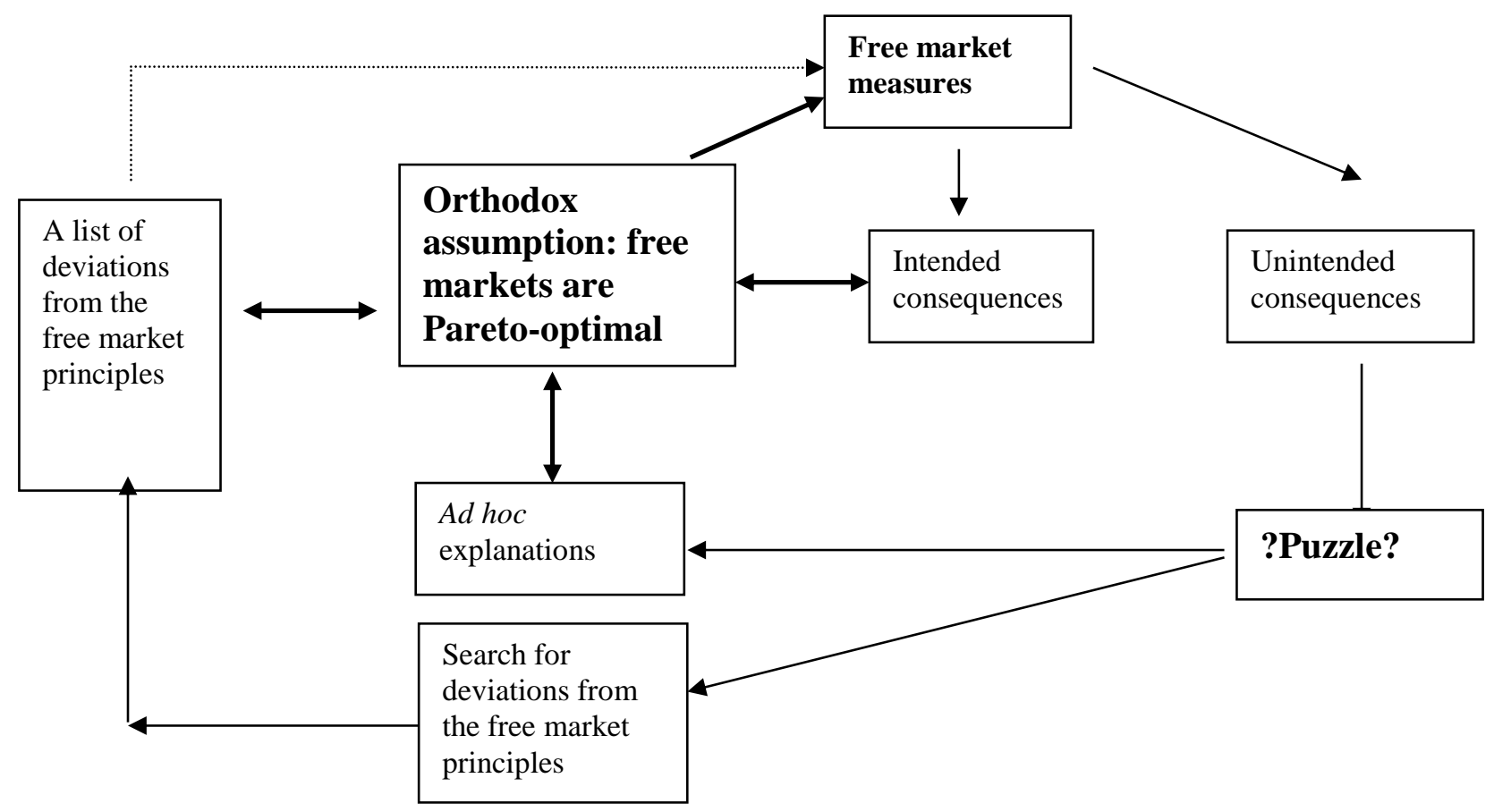

Source: Patomäki 2001, 12

Ad hoc explanations are typically combined with the search for deviations from the free market rules and principles or policy failures that would co-explain why the optimal outcome was not yet reached. With these ad hoc explanations, the prevailing 
theory is being vindicated (for instance, mainstream economics was not only unable to anticipate the global financial crisis of 2008-2009, but it has also been unable to learn from it; see Bigo and Negru 2014; Mirowski 2014; Morgan 2015). In accordance with this logic, the usual political solution has been to impose the free competitive markets ideal even more vigorously, although some contrary reregulation may also occur (indicating that the circle of Figure 2 is not fully closed). This methodological and normative problem is not unique to the efficient markets hypothesis and like-minded economic theories (see Patomäki, forthcoming), however hegemonic they may be during the current era. Reflexivity, performativity and openness of social systems pose problems to any episteme.

Figure 3: Accuracy, desirability, falsifiability and exploitability of public predictions

\begin{tabular}{|c|c|c|c|c|c|}
\hline Prediction & $\begin{array}{l}\text { Predicted } \\
\text { outcome }\end{array}$ & Accuracy & Falsification & $\begin{array}{c}\text { Strategic } \\
\text { exploitation }\end{array}$ & $\begin{array}{l}\text { Ideological } \\
\text { exploitation }\end{array}$ \\
\hline \multirow[t]{2}{*}{ Non-self-altering } & Desirable & Useless & $\begin{array}{l}\text { Relatively } \\
\text { trouble-free }\end{array}$ & Not possible & Not possible \\
\hline & Non-desirable & "'” & "'” & "'” & "'” \\
\hline \multirow[t]{2}{*}{ Net effect zero } & Desirable & Useless & $\begin{array}{l}\text { Requires } \\
\text { counterfactual } \\
\text { reasoning }\end{array}$ & $\begin{array}{l}\text { Possible (what } \\
\text { outcome is good } \\
\text { or bad for } \\
\text { whom?) }\end{array}$ & $\begin{array}{l}\text { Possible (what } \\
\text { outcome is } \\
\text { considered } \\
\text { good or bad by } \\
\text { whom?) }\end{array}$ \\
\hline & Non-desirable & "'” & "'” & "'” & "'” \\
\hline \multirow[t]{2}{*}{ Net self-fulfilling } & Desirable & Helpful & "'” & "'" & "'" \\
\hline & Non-desirable & Harmful & "'” & "'” & "'” \\
\hline \multirow[t]{2}{*}{ Net self-denying } & Desirable & Harmful & "'” & "'” & "'” \\
\hline & Non-desirable & Helpful & "'” & "'” & "'” \\
\hline
\end{tabular}

Thus, what we have is a complicated picture consisting of the direction of selfalteration; desirability of the counterfactual and actual outcomes; counterfactual reasoning and the absence of decisive test situations; and possibility of strategic and ideological exploitation of predictions. Figure 3 summarises the key points in terms of accuracy, desirability, falsifiability, and exploitability of prediction. Note that in the cases of non-self-altering predictions and zero net effect, accuracy may be desirable but is practically useless. Whenever reflexivity plays a role, falsification requires counterfactual reasoning and is especially difficult. Strategic and ideological exploitation of predictions decomposes the desirability of outcome in terms of selfinterested actors and different normative conceptions of common good.

From strategic actions and ideologies to emancipation from false necessities 
The aim of social sciences is not to predict accurately, but to bring about desirable outcomes (cf. Sayer 2011). Accurate anticipations, when conceived counterfactually, can sometimes be helpful toward achieving this aim, depending on the net selfaltering effect. Because of the possibility of exploitation of predictions, we must also ask: what outcome is good or bad for whom; and what outcome is considered good or bad by whom and on what generalizable grounds? Reflexivity encourages us to replace mere prediction by scenarios of possible futures comprising different possible courses of action and policies by various actors, including "us" (whomever this "us" may be). When the reflexivity of predictions becomes transparent and publicly known, scenarios about possible futures become necessarily entangled with public ethico-political discourse about the problems and merits of different outcomes (for instance in terms of discourse ethics, see Apel 2001; and Habermas 1990).

According to Merton's analysis of self-fulfilling prophecies, behaviour based on false beliefs can generate a social situation that accords with those false beliefs. Now, social sciences are committed to truth. The task of social scientific explanation is to form a plausible and empirically confirmed true picture of geo-historical components and their relations. As social scientists, we evaluate negatively those parts of the institutional context that are responsible for the re-production of (self-fulfilling) false beliefs. (See Bhaskar 1998, 59-71; Patomäki 2002, 143-63). The type of situation that Merton describes is thus inherently problematical. One is justified in characterising a set of beliefs as "ideological" if both (i) many or all of those beliefs are false, that is, one possesses a superior explanation of the phenomena; and (ii) one possesses an explanation of the falsity of those beliefs and why they are held.

Let me develop Merton's example of a bank run a bit further. An actor may know the claim "bank X is unstable and is thus likely to collapse" to be false. It may still remain rational for her to participate in making the prediction come true. Either she believes that a sufficient number of actors believe the claim; or she believes that a sufficient number of actors believe that others believe it (see Lagerspetz 1988, 3089). There can be still higher levels, resembling Keynes's famous beauty contest. ${ }^{9}$ Real world contradictions of this sort are not categorical because the outcome depends on contingent circumstances, in this case how many individuals are in fact intending to withdraw their savings simultaneously. Actors may nonetheless be trapped in an ideology sustained by lack of trust and suspicions about the motivation of others. This is a temporary and specific "ideology", but it shows how false beliefs can lead to

\footnotetext{
${ }^{9}$ Keynes (1961/1936, 155-8) compared speculation to a newspaper beauty contest, in which the aim is not to compare and rank the beauty of the contestants as such but rather to forecast what features the average observer will find beautiful. There are different levels in this sort of competition: at the second level guesses are made as to what the firstlevel players will decide, and the third-level players guess what the second-level players will decide, and so on. This description fits well to the activities of speculative finance - with the proviso that here the situation is of course more complicated, in that there are very many competitions going on all at once, each with a great many players and levels.
} 
undesirable and unnecessary outcomes, which can be prevented by building better common institutions. The simplest institutional solution to this particular problem is deposit insurance. Experiences from bank runs during the Great Depression led to the introduction of deposit insurance in many countries.

Reflexivity means the capacity of actors to reflect on their own conditions and place, accepting that both can change and be changed. Earlier I argued that a credible forecast of increased inflation can bring about both self-denying (monetary and financial countermeasures by the government and central bank) and self-fulfilling responses (workers increase wage demands, corporations increase prices). However, this underestimates the diversity of values and the powers of human reflexivity and freedom. Increased inflation is not necessarily a bad thing. The desirability of higher inflation depends on the base level, economic theories and values. Increasing inflation from $0 \%$ to $2 \%$ is desirable even from the point of view of the ECB. A Keynesian might argue for a higher rate, say around $5 \%$. As a general rule low inflation favours lenders and those who possess money-capital; higher inflation favours debtors such as entrepreneurs and home-owners. Even when rising inflation is seen as a problem, relevant actors such as workers and corporations can be persuaded either to behave responsibly or to reach an agreement that counters the tendency toward prediction-accelerated cost-push inflation. This may, however, be difficult because of conflicts over income and power distribution.

At this point reflexive ethico-political discourse moves to a deeper and more general level concerning the way social institutions should be organised. For instance, for John Rawls (1971, 3-4) "justice is the first virtue of social institutions". Laws and institutions, no matter how efficient and well-arranged, "must be reformed or abolished if they are unjust". What would be a just way of organising institutions of political economy? What is the proper rate of saving over time, how should the background institutions of taxation and property be arranged, and at what level is the social minimum or redistributive principles to be set? Within an institutional arrangement perceived as just and legitimate, it should be easier to behave responsibly and reach agreements about common good concerning for instance inflation.

In some contrast to Rawls, however, it is also plausible to argue that because of the relativist nature of struggles between models and sentiments of justice, the first priority would be to organise public discourses and collective will-formation and decision-making democratically (see Perelman 1963; Patomäki 2006). Notably, some theories of justice emphasize the importance of democratic processes more than others. Schweickart (1993), for instance, argues that fairness is essentially (also) about deciding democratically upon economic rules and procedures and goals of economic institutions. He proposes a project of specifying a model of an economically feasible, morally desirable alternative to capitalism (ibid, 116). Hereby 
we can see that deep behind the contingent predictability of responses lies the performativity of social and economic theories. Historically evolving and changing theories condition, shape and constitute those institutions on which the basic character and responsiveness of different actors depend.

Instead of performativity, we could also talk about "ideational reflexivity" whereby "ideas about the economy reflect back on and affect or shape the evolving economy" (Mackinnon 2005, 6). Ideas can shape the construction of institutions as well as agendas and actions of economic actors and their responses to policy. Public discussion and debate about these ideas is at the heart of democratic political processes. Actors come to realise, reflexively, that the future is not something that just happens and can be predicted, but rather becomes increasingly something that the actors, including "us", make of it.

This is a learning process that occurs through reflexive feedback loops where also the course of real history influences participants' views and theories. In the complex interdependent processes of world economy consisting of billions of actors, both individual and collective, and their structurally conditioned responses and collectively constituted modes of responsiveness, it is never possible to fully replace strategic actions and reflexive predictions with public discourses and common agreements. Rational economic policy will require at least some predictive capacities also in the future, and for this we must, in part, rely on contrastive demi-regularities and our knowledge about the structures and mechanisms that generate them, as well as on anticipation of actors' responses including to policy changes and regime shifts. Yet the degree of human freedom can be increased by replacing particular unnecessary and often misrepresented causal sources of determination with more wanted and needed and also more clearly evident sources of causal determination.

\section{$\underline{\text { Conclusions }}$}

In econometrics, a structural break, or structural change, is an unexpected shift in a time series that can lead to forecasting errors and general unreliability of the model. This definition refers to a specific technical function in econometric modelling. Data is nothing, however, more than external traces of internal contents. There are multiple layers of contradictory and complementary determination to which these traces owe their hidden unities, divergent meanings, and possible futures (Alker 1996, 351). The data is generated by (i) real causal complexes and (ii) data-coding, data-collection and dat-manipulation procedures. Not only these two layers but also econometric methods themselves can result in "structural breaks" in the technical sense of the term. What is interesting from a social scientific point of view are the real causal complexes consisting of actors, actions, rules, resources, practices and structures. 
When a statistical measure or relationship changes from being a mere indicator to an object of policy for control purposes, its meaning changes. What is more, profitmotivated capitalist firms and investors may change their expectations and find new opportunities in the newly defined situation, changing their agendas and behaviour accordingly. The announced policy-change can be seen as a self-altering prediction (or involving such a prediction), which is subject to contradictory and complementary determination, resulting either in net self-fulfilling or self-denying tendency. Whether the effect of these kinds of changes is strong enough to constitute a "structural break" at the level of econometrics, is contingent and can be tested, although we also know that the reliability of these tests is uncertain (the nature and quality of economic data sets definite limits to the use of these methods; e.g. Atkinson \& Brandolini 2009).

The changing and reflexive nature of reality has important policy-implications. What works and what does not work becomes a matter of timing and experimentalism. Take the Keynesian multiplier for instance. The multiplier is not a constant, not even in a given national "economy". The multiplier can vary a lot over different phases of the business cycle and because of changes in policies, practices and institutions (policy can shape for instance the marginal propensity to consume). The overall multiplier can also be strengthened or dampened by the responses of other states and international organizations. These responses co-depend on reflexive anticipations of the effects of decreasing or increasing public expenditure for particular purposes. It is possible to try to persuade other states and international organizations either to behave responsibly or to reach an agreement that counters deflationary tendencies. What is "responsible" and when do "deflationary tendencies" prevail are dependent our understandings of political economy - and thus subject to public debates.

The EU is an example of complex system of governance that relies on circular feedback loops and predictions that become easily self-fulfilling. The problem is that these loops are built on the assumption that the predicted outcome is negative (too much public debt) and that the prediction is net self-denying (cf. figure 3 ). In reality, the sustainable level of public debt is open to debate and predictions tend to be selffulfilling both through the financial disciplinary mechanism and multiplier effect. The underlying problem has to do with ideational reflexivity and the closed circle of operation of the efficient market hypothesis and likeminded theories (figure 2). The EU system of governance is thus, in part, premised on false beliefs that it then reproduces in a self-fulfilling manner. We should evaluate negatively those parts of the institutional context that are responsible for the re-production of (self-fulfilling) false beliefs. The undesirable and unnecessary outcomes could easily be prevented by building better common institutions (see Patomäki 2013, chapter 6-8).

It is striking that there are regular patters in capitalist market economy, although it is changing and evolving over time, the boom-and-bust cycle being a case in point. In anticipation of the next global financial crisis and recession or depression, we may 
also ask, what will happen to the EU as the circular feedback loops involving selffulfilling predictions remain in place. The EU governance system amplifies differences and changes. Thus, a negative shock is likely to lead to more divergent paths of development, strengthening the disintegrative tendencies within the Union (see Patomäki 2018, 122-7. However, neither a new global crisis nor the disintegration of the EU is necessary. The future is not something that just happens but rather something that actors, including "us", make of it.

\section{List of references}

Alker, H. 1996. Rediscoveries and Reformulations. Humanistic Methodologies for International Studies. Cambridge: Cambridge University Press.

Apel, K. 2001. The Response of Discourse Ethics to the Moral Challenge of the Human Situation as Such and Especially Today. Leuven: Peeters.

Atkinson, A. and Brandolini, A. 2009. "On data: A Case Study of the Evolution of Income Inequality Across Time and Across Countries", Cambridge Journal of Economics, vol. 3, no. 3, pp. $381-404$.

Barro, R. 1974. “Are Government Bonds Net Wealth?”, Journal of Political Economy, vol. 82 no. 6, pp. 1095-1117.

Bhaskar, R. 1998. The Possibility of Naturalism. A Philosophical Critique of the Contemporary Human Sciences. Third edition. London \& New York: Routledge.

Bigo, V. and Negru, I. 2014. "Mathematical Modelling in the Wake of the Crisis: A Blessing or a Curse? What Does the Economics Profession Say?", Cambridge Journal of Economics, vol. 38, no. 2, pp. 329-347.

Bronk, R. 2013. "Reflexivity Unpacked: Performativity, Uncertainty and Analytical Monocultures", Journal of Economic Methodology, vol. 20, no. 4, pp. 343-349.

Centre for Research on Multinational Corporations. 2011. "Newsletter - EU Financial Reforms", part of the project Towards a Global Finance System at the Service of Sustainable Development. (http://somo.nl/dossiers-en/sectors/financial/eu-financial-reforms/newsletters).

Chao, H. 2000. "Milton Friedman and the Emergence of the Permanent Income Hypothesis", LSE Centre for Philosophy of Natural and Social Science Measurement in Physics and Economics, Technical Report 9/2000 (http://www.lse.ac.uk/CPNSS/pdf/ DP withCoverMeasurement/MeasDP\%2009\%2000.pdf).

Chick, Victoria \& Dow, Sheila (2005) “The Meaning of Open Systems”, Journal of Economic Methodology, vol. 12, no. 3, pp. 363-381. 
Clements, M.P. and Hendry, D.F. 1999. "On Winning Forecasting Competitions in Economics", Spanish Economic Review, vol. 1 no. 2, pp. 123-160.

Council of the European Union 2012. "Treaty on Stability, Coordination, and Governance in the Economic and Monetary Union" (https://www.consilium.europa.eu/media/20399/

st00tscg26_en12.pdf).

Dequech, D. (2011) “Uncertainty: A Typology and Refinements of Existing Concepts”, Journal of Economic Issues, vol. 45, no.3, pp. 621-640.

Duesenberry, J.S. 1949. Income, Saving and the Theory of Consumer Behaviour. Cambridge, MA: Harvard University Press.

European Commission 2018. "Spring 2018 Economic Forecast - Statistical annex". (https://ec.europa.eu/info/files/economy-finance/spring-2018-economic-forecast-statisticalannex_en).

European Parliament Think Tank 2018. "Structural budget balances in EU Member States". (http://www.europarl.europa.eu/RegData/etudes/BRIE/2017/587388/IPOL_BRI(2017)587388_EN. pdf).

Fama, E. 1970. "Efficient Capital Markets: A Review of Theory and Empirical Work", Journal of Finance, vol. 25 no. 2, pp. 383-417.

Friedman, M. 1957. A Theory of the Consumption Function. Princeton, NJ: Princeton University Press. (http://papers.nber.org/books/frie57-1).

Giddens, A. 1979. Central Problems in Social Theory. Los Angeles: University of California Press.

Gordon, R.J. 1976. "Can econometric policy evaluations be salvaged? - A comment", CarnegieRochester Conference Series on Public Policy, vol. 1, pp. 47-61.

Goodhart, C. 1981. "Problems of Monetary Management: The U.K. Experience", in A.S. Courakis (ed.), Inflation, Depression, and Economic Policy in the West. Totowa, New Jersey: Barnes \& Noble Press, pp. 111-146.

Grunberg, E. \& Modigliani, F., 1954. "The Predictability of Social Events", Journal of Political Economy, vol. 62, no. 6, pp.465-478.

Habermas, J. 1990. Moral Consciousness and Communicative Action, trans. by C. Lenhardt and S.Weber Nicholsen. Cambridge, MA: The MIT Press.

Hendry, D. F. 1983. "On Keynesian Model Building and the Rational Expectations Critique: A Question of Methodology”, Cambridge Journal of Economics, vol. 7, pp. 69-75.

Hendry, D. F. 1985. "Monetary Economic Myth and Econometric Reality", Oxford Review of Economic Policy, vol. 1, no. 1, pp. 72-84.

Hendry, D.F. 1997. “The Econometrics of Macroeconomic Forecasting”, Economic Journal, vol. 107, issue 444, pp. 1330-57. 
Henshel, R.L. 1993. "Do Self-Fulfilling Prophecies Improve or Degrade Predictive Accuracy? How Sociology and Economics Can Disagree and Both Be Right", The Journal of Socio-Economics, vol. 22, no. 2, pp. 85-104.

Herman, E. S. 1995. Triumph of the Market: Essays on Economics, Politics and the Media. Boston: South End Press.

International Monetary Fund. 2016. Global Financial Stability Report-Fostering Stability in a Low-Growth, Low-Rate Era. Washington, DC: International Monetary Fund.

International Monetary Fund. 2017. Global Financial Stability Report: Is Growth at Risk? Washington, DC: International Monetary Fund.

International Monetary Fund. 2018. Global Financial Stability Report: A Bumpy Road Ahead. Washington, DC: International Monetary Fund.

Keynes, J. M. 2008/1920. A Treatise on Probability. London: Rough Draft Printing/MacMillan.

Keynes, J.M. 1961/1936. The General Theory of Employment, Interest and Money. London: MacMillan.

Kindleberger, C. 1978. Manias, Panics, and Crashes: A History of Financial Crises. London: MacMillan.

Lagerspetz, E. 1988. "Reflexive Predictions and Strategic Actions", Social Science Information, vol. 27, no. 2, pp.307-20.

Lawson, T. 2007. Economics and Reality. London: Routledge.

Lawson, T. 2015. The Nature and State of Modern Economics. London: Routledge.

Lucas, R. E. 1972. "Expectations and the Neutrality of Money", Journal of Economic Theory, vol. 4 no. 2, pp. 103-24.

Lucas, R.E. 1976. "Econometric Policy Evaluation: A Critique”, in K. Brunner \& A. Meltzer (eds.), The Phillips Curve and Labor Markets, Amsterdam: North Holland Publishing Company, pp. 1946.

Martins, N.O. 2018. "Critical Realism, Economics, and Heterodox Economics", in F.S. Lee, B. Cronin, \& E. Elgar (eds.), Handbook of Research Methods and Applications in Heterodox Economics, Cheltenham \& Northampton: Edward Elgar Publishing, pp. 222-36.

MacKenzie, D. 2006. An Engine, Not a Camera: Finance Theory and the Making of Markets. Cambridge: MIT Press.

MacKenzie, D., Muniesa, F., \& Siu, L. 2007. Do Economist Make Markets? On The Performativity of Economics. Princeton: Princeton University Press. 
Mackinnon, L. 2005. "Ideational Reflexivity in Economic Systems”, in L. Mackinnon, "The social construction of economic man: The genesis, spread, impact and institutionalisation of economic ideas”. Unpublished doctoral dissertation, Brisbane: University of Queensland, Ch 11. (https://espace.library.uq.edu.au/view/UQ:8777).

Merton, R. K. 1948. “The Self-Fulfilling Prophecy”, The Antioch Review, vol. 8, no. 2, pp. 193-210.

Minsky, H. 1982. Can “It” Happen Again? Essays on Instability and Finance. Armonk, New York: M.E. Sharpe.

Minsky, H. 2008. Stabilizing and Unstable Economy. 2nd edition. New York: McGraw Hill.

Mirowski, P. 2014. Never Let a Serious Crisis Go To Waste. How Neoliberalism Survived the Financial Meltdown. London: Verso.

Morgan, J. 2015. "Is Economics Responding to Critique? What do the UK 2015 QAA Subject Benchmarks Indicate?", Review of Political Economy, vol. 27, no. 4, pp.518-538.

Nasir, A. and Morgan, J. 2018. "The Unit Root Problem: Affinities between Ergodicity and Stationarity, Its Practical Contradictions for Central Bank Policy, and Some Consideration of Alternatives", Journal of Post Keynesian Economics, first online 10 Apr 2018, DOI: 10.1080/01603477.2017.1387060.

Palley, T. I. 2013. "Financialization: What it is and Why it Matters", Financialization. London: Palgrave Macmillan, pp. 17-40.

Patomäki, H. 2001. Democratising Globalisation. The Leverage of the Tobin Tax, London: Zed Books.

Patomäki, H. 2002. After International Relations. Critical Realism and the (Re)Construction of World Politics, London and New York: Routledge.

Patomäki, H. 2006. "Global Justice: A Democratic Perspective”, Globalizations, vol. 3, no. 2, pp.99-120.

Patomäki, H. 2010. "What Next? An Explanation of the 2008-9 Slump and Two Scenarios of the Shape of Things to Come", Globalizations, vol. 7, no. 1, pp. 67-84.

Patomäki, H. 2013. The Great Eurozone Disaster: From Crisis to Global New Deal. London \& New York: Zed Books.

Patomäki H. 2017. "Capitalism: Competition, Conflict, Crisis”, Journal of Critical Realism, vol. 16, no. 5, pp. 537-543.

Patomäki, Heikki. 2018. Disintegrative Tendencies in Global Political Economy: Exits and Conflicts. London \& New York: Routledge.

Patomäki H. (forthcoming). "The Ideal of Competitive Markets. On The Social Psychology and Politics of Neoclassical Theory", resubmitted after major revisions to Cambridge Journal of Economics in June 2018, pending for final decision. 
Perelman, C. 1963. The Idea of Justice and the Problem of Argument. London: Routledge \& Kegan Paul.

Pratten, S. 2005. "Economics As Progress: The LSE Approach to Econometric Modelling and Critical Realism as Programmes for Research", Cambridge Journal of Economics, vol. 29, no. 2, pp. 179-205.

Rawls, J. 1971. A Theory of Justice. The original edition. Cambridge, MA: The Belknap Press of Harvard University Press.

Reid, J., Nicol, C., Burns, N. \& Chanda, S. 2017. Long-Term Asset Return Study: The Next Financial Crisis, London: Deutsche Bank Markets Research.

Robinson, J. 1980. “Time in Economic Theory”, Kyklos, vol. 33, no. 2, pp. 219-229.

Sayer, A. 2011. Why Things Matter to People. Social Science, Values and Ethical Life. Cambridge: Cambridge University Press.

Sargent, T. and Wallace, N. 1975. "Rational" Expectations, the Optimal Monetary Instrument and the Optimal Money Supply Rule”, Journal of Political Economy, vol. 83, no. 2, pp. 231-54.

Schumpeter, J. 1939. Business Cycles, Vol. 1. New York and London: McGraw-Hill.

Simon, H.A. 1954, "Bandwagon and Underdog Effects and the Possibility of Election Predictions", Public Opinion Quarterly, vol. 18, no. 3, pp. 245-253.

Sims, C.A., Goldfeld, S.M. \& Sachs, J.D. 1982. "Policy Analysis with Econometric Models", Brookings Papers on Economic Activity, vol. 1982, no. 1, pp. 107-164.

Soros, G. 1998. The Crisis of Global Capitalism: Open Society Endangered. London: Little, Brown \& Co.

Soros, G. 2008. The Crash of 2008 and What it Means: The New Paradigm for Financial Markets. Melbourne: Scribe.

Soros, G. 2013. "Fallibility, Reflexivity, and the Human Uncertainty Principle", Journal of Economic Methodology, vol. 20, no. 4, pp. 309-329.

Shaikh, A. 2013. "On the Role of Reflexivity in Economic Analysis", Journal of Economic Methodology, vol. 20, no. 4, pp. 439-445.

Shaikh, A. 2016. Capitalism: Competition, Conflict, Crises. Oxford University Press, New York.

Stiglitz, J. E. 2010. "Lessons from the Global Financial Crisis of 2008”, Seoul Journal of Economics, vol. 23, no. 3, pp. 321-39 (https://www8.gsb.columbia.edu/faculty/jstiglitz/sites/ jstiglitz/files/2010_Lessons_Global_Financial_Crisis_Seoul.pdf). 
Schweickart, D. 1993. “A Democratic Theory of Economic Exploitation Dialectically Developed”, in R. Gottlieb, R. Radical Philosophy. Tradition, Counter-Tradition, Politics. Philadelphia: Temple University Press, pp. 101-22.

Van der Zwan, Natascha. 2014. "Making Sense of Financialization", Socio-Economic Review, vol. 12, no. 1, pp. 99-129.

Wilcox, D. 1989. "Social Security Benefits, Consumption Expenditure, and the Life Cycle Hypothesis”, Journal of Political Economy, vol. 97, no. 2, pp. 288-304. 